\title{
Alfons Przybyła
}

\section{Zasada legalności w kościelnym prawie karnym}

Prawo Kanoniczne : kwartalnik prawno-historyczny 14/1-2, 225-252

1971

Artykuł został zdigitalizowany i opracowany do udostępnienia w internecie przez Muzeum Historii Polski w ramach prac podejmowanych na rzecz zapewnienia otwartego, powszechnego i trwałego dostępu do polskiego dorobku naukowego i kulturalnego. Artykuł jest umieszczony w kolekcji cyfrowej bazhum.muzhp.pl, gromadzącej zawartość polskich czasopism humanistycznych i społecznych.

Tekst jest udostępniony do wykorzystania w ramach dozwolonego użytku. 


\section{ALFONS PRZYBYEA}

\section{ZASADA LEGALNOSCI W KOSCIELNYM PRAWIE KARNYM}

Treść: Wstęp. I. Pojęcie, II. Charakter prawny, III. Rozwój historyczny, A. W prawie państwowym, B. W prawie kanonicznym, IV. Zasada legalności w KPK, V. Wnioski de lege ferenda

\section{Wstep}

Współczesne ustawodawstwa karne szczycą się zasadą tzw. 1egalności, która streszcza się w tradycyjnej formie: „nullum crimen, nulla poena sine lege poenali praevia" - nie ma przestępstwa, nie ma kary bez uprzedniej ustawy karnej. Wyraża ona najogólniej rzecz biorąc — zakaz poczytywania bezprawnego czynu za przestępstwo i karania jego sprawcy, jeżeli przekroczona ustawa nie jest obwarowana sankcją karną, czyli nie przewiduje za taki czyn żadnej kary.

Zasada ta nie jest też obca wspólczesnemu prawu kanonicznemu. Jednakże Kodeks prawa kanonicznego nie formułuje jej dostatecznie jasno, co powoduje wśród kanonistów dużą rozbieżność zdań na ten temat. Stawia się nawet pytanie, czy w ogóle kościelne prawo karne tę zasadę przyjmuje. Ponadto od pewnego czasu, a zwłaszcza teraz w okresie posoborowym, gdy oczekuje się nowego Kodeksu prawa kanonicznego, wielu kanonistów wysuwa $\mathrm{w}$ odniesieniu do tego zagadnienia tzw. wnioski de lege ferenda. Są one też rozbieżne jak i same opinie dotyczące interpretacji przepisów Kodeksu określających wspomnianą zasadę legalności. Zagadnienie to zdaje się stanowić jedną z najsporniejszych kwestii we. współczesnej nauce prawa kanonicznego. Ponieważ opinie poszczególnych autorów dotyczące tego zagadnienia są wypowiadane raczej ubocznie w różnych artykułach, rozrzuconych $\mathrm{w}$ wielu czasopismach, lub też bardzo skrótowo przedstawiane w opracowaniach podręcznikowych, przeto chyba warto będzie bliżej się tej kwestii przyjrzeć i przedstawić pełny jej zarys. 


\section{Pojęcie zasady legalności w prawie karnym}

Formuła: „Nullum crimen, nulla poena sine lege poenali praevia", jak to wyraźnie z jej brzmienia wynika składa się z dwóch członów i - choć na pierwszy rzut oka zdaje się wyrażać jedną i tę samą myśl - zawiera dwie różniące się $w$ pewnym stopniu zasady karno-prawne 1.

I tak pierwsza głosi: „nullum crimen sine lege poenali prae-via" - nie ma przestępstwa bez uprzedniej ustawy karnej. Wyraża ona zakaz poczytywania sprawcy za przestępstwo czynu, który - aczkolwiek społecznie szkodliwy - nie jest zakazany ustawą karną, uprzednio ogłoszoną. Przez ustawę karną - legem poenalem - w odróżnieniu od ustawy czysto dyscyplinarnej czyli nie karnej rozumie się taką ustawę, która prócz nakazu lub zakazu określonego postępowania lub zachowania się zawiera w sobie sankcję karną, tzn. nakazuje lub zakazuje jakiegoś czynu i jednocześnie grozi karą temu, kto się jej w przyszłości nie podporządkuje ${ }^{2}$. Ponadto we wspomnianej zasadzie mieści się jeszcze zakaz zwiększania odpowiedzialności karnej sprawcy za poczytane mu przestępstwo ze względu na okoliczności obciążające, które nie są jako takie w danym ustawodawstwie karnym wyraźnie przewidziane.

Druga natomiast reguła w słowach: „nulla poena sine lege poenali praevia" - zakazuje wymierzać sprawcy kary za przypisane mu przestępstwo, jeżeli nie jest ona w obowiązującym ustawodawstwie przewidziana. Tak więc, gdy pierwsza regula dotyczy oceny samego czynu jako przestępstwa karnego, to druga odnosi się do samej odpowiedzialności karnej i wymiaru kary. Przeto, choć gloszą tę samą ideę legalności w prawie karnym i - wypowidziane $\mathrm{w}$ przytoczonej wyżej formule ściągniętej — zdają się wyrażać pewnego rodzaju tautologię, różnią się jednak znacznie od siebie. Dotycząc bowiem różnych przedmiotów, nie koniecznie jedna pociąga za sobą drugą i stąd nie zawsze muszą iść w parze ze sobą lub przynajmniej w różnym stopniu mogą byé realizo-

1 For. V a s a 11 i G., Nullum crimen sine lege, Torino 1939, 9 i nn.; K 1 ein J., Skandalon. Um das Wesen des Katholizismus, Tübingen 1958, 211, nota 55; P eters K., Strafzumessung, w: Staatslexikon, Freiburg im Br. 1962, t. VII, 785; Herman n H., Erwägungen zu einer Revision des c. 2222, Oesterreichisches Archiv für Kirchenrecht 20 (1969) 3 , nota 3 .

2 Co do struktury przepisu karnego por. Peperoni S., Lineamenta iuris poenalis canonici, Romae 1966, 88; Andrejew I., Lerne 11 I., $\mathrm{S}$ a w i cki J., Prawo karne, Cz. og. Warszawa 1954, t. I, 248; L e rn e 11 L., Wyktad prawa karnego, Cz. og., Warszawa 1961, 21 i n.; S w id a W., Prawo karne, Cz. agó., Warszawa 1966, 54 i nn.; C a v a 11 o V., Diritto penale 2 , P. gen., v. I. Napoli 1962, 292 i nn.; Antol is e i F., Manuale di diritto penale 5 , P. gen., Milano 1963, 30. 
whe $w$ jednym i tym samym prawodawstwie. I tak np. niektóre ustawodawstwa, przyjmujące bez żadnych zastrzeżeń zasadę: „nullum crimen sine lege', wymiar kary, czyli jej określenie tak co do rodzaju jak i co do wielkości, pozostawiaja roztropnemu uznaniu sędziego. Inne zaś idą jeszcze dalej. Mianowicie podtrzymują calkowicie powyższą zasadę legalności w odniesieniu do kwalifikacji czynu jako przestępstwa, ale pod wpływem pozytywistycznych tendencji do przesadnej indywidualizacji kary $i \mathrm{w}$ związku $z$ instytucją warunkowego zwolnienia dopuszczają tzw. skazania nieokreślone, czyli wyroki karne skazujące przestępców na kary zupełnie nie oznaczone co do ich trwania lub pozwalające na zmianę kary w ciągu jej odbywania, co zdaje się wyraźnie sprzeciwiać zasadzie: „nulla poena sine lege" 3 .

Zasada legalności w prawie karnym jest przez niektórych autorów szerzej pojmowana. Mianowicie podciągają pod nią również zakaz stosowania analogii, szerokiej interpretacji ustaw karnych i opierania się na zwyczaju przy wymierzaniu kar. Chcąc jednak poprawnie rzecz traktować pod względem metodologicznym, nie powinno się tych trzech zakazów mieszać. Z dosłownego bowiem znaczenia formuly: „nullum crimen nullaque poena sine lege poenali praevia" wcale nie wynika ani zakaz stosowania analogii, czyli przenoszenia normy zawartej $w$ pewnym przepisie karnym $i$ dotyczącej typowo określonego zachowania się na inny analogiczny stan faktyczny tym przepisem nie objęty, ani zakaz posługiwania się szeroką interpretacją normy karnej. Sędzia bowiem uciekający się do analogii lub do szerolkiej interpretacji w przypisywaniu sprawcy przestęstwa i wymiarze kary, jeżeli dany system prawny mu na to zezwala, stosuje po prostu ustawę karną czyli obraca się jeszcze w granicach legalności. Z drugiej strony zakaz stosowania analogii i szerolkiego tłumaczenia ustaw karnych może się odnosić do wszystkich przepisów prawa karnego, podczas gdy problern zasady legalności dotyczy tylko tych norm, które określaja poszczególne przestepstwa i odpowiednie dla nich sankcje karne, czyli coś nakazują lub czegoś zakazują pod groźbą kary, oraz tych, które ustalają okoliczności obciążające tzn. zwiększające odpowiedzialność karną sprawcy. Zresztą same ustawodawstwa najczęściej te trzy zagadnienia — legalności, analogii i interpretacji — wyraźnie oddzielają, normując je osobnymi przepisami. Można się też spotkać $z$ wypadkiem, że pewne ustawodawstwo karne przyjmuje zasadę legalności, a pomija inne wymienione zakazy lub odwrotnie 4.

Bliżej już łączy się z problemem legalności w prawie karnym

3 Por. Vas sa 11 i G., dz. c., 11 i nn.

4 Por. Vas s a 11 i G., dz. c., 5 i nn. 
zagadnienie niewsteczności ustaw karnych. Zasada niewsieczności ustawy polega na tym, że ustawa nie działa wstecz - retro non agit, czyli jej moc wiążąca nie obejmuje tych wypadków konkretnych, typowo $\mathrm{w}$ niej określonych, które zaszły przed wejściem jej w życie, lecz sięga naprzód i dotyczy tylko tych wypadków, które w przyszłości — od momentu wejścia jej w życie - będą miały miejsce ${ }^{5}$. Ściśle rzecz biorąc, trzeba powiedzieć, że i zasada niewsteczności ustaw karnych, choć bliska jest zasadzie legalności, nie pokrywa się $z$ nią calkowicie i w wielu współczesnych ustawodawstwach karnych jest osobno traktowana czyli regulowana oddzielnymi przepisami. Nic też nie stoi na przeszkodzie, aby przy całkowitym zastosowaniu zasady legalności mogły być przyjęte pewne odchylenia od zasady niewsteczności 6 .

Tak więc zasada: „,nullum crimen nullaque poena sine lege poenali praevia" w ścisłym ujęciu wyraża jedynie postulat, aby wymiar sprawiedliwości karnej opieral się na obowiązujących ustawach karnych, określających typowo znamiona poszczególnych przestępstw $i$ wyznaczających za nie odpowiednie kary, a nie na zwyczaju lub dowolnym uznaniu sędziego.

\section{Charakter prawny zasady legalności}

Zasada legalności $w$ prawie karnym nie jest postulatem prawa naturalnego czyli wymogiem bezwzględnym, lecz zakazem czysto pozytywnym. Prawo bowiem naturalne do tego, aby jakiś czyn można było poczytać jego sprawcy zá przestępstwo $\mathfrak{i}$ wymierzyć mu zasłużoną karę, wcale nie nakazuje, by czyn ten był uprzednio nakazany lub zakazany pod groźbą kary, lecz wymaga jedynie, aby byl przez sprawcę zawiniony i naruszal porządek spoleczny a jego napiętnowanie i ukaranie było konieczne dla obrony tego porządku.

Kara bowiem $w$ znaczeniu prawnym polega na pozbawieniu kogoś określonego dobra czyli zadaniu mu pewnej dolegliwości w celu pomszczenia jego czynu społecznie szkodliwego i przywrócenia $\mathrm{w}$ ten sposób naruszonego porządku prawnego. Nie godzi się jednak nikogo pozbawiać przysługującego mu dobra, czy zadawać mu

5 Por. Van Hove A., De legibus ecclesiasticis, Mechliniae 1930, n. 29 i nn.; Brys J., Tractatus de legibus, Brugis 1942, s. 44; M ichi els G., Normae generales iuris canonici2, Parisiis Tornaci - Romae, 1949, v. I, 228 i nn.; Petron celli M., Il principio della non retroattivita delle leggi in diritto canonico, Milano 1931, 1 i nn., 41 i nn.; Cicognani H. J., - Staffa D., Commentarium ad librum I Codicis Iuris Canonici, Romae 1939, I, 173 i nn.; An drie u-Guitrancourt P., Introduction a l'étude du droit en général et du droit canonique contemporain, Paris 1963, 926.

${ }^{6}$ Por. Vas salli G., dz. c., 14 i nn. 
dolegliwości bez jego winy i bez racji podyktowanych przez interes publiczny. Stąd więc dla słusznego wymierzenia komuś kary naturalny porządek rzeczy wymaga, aby czyn karany był zawiniony $\mathrm{i} \dot{z}$ eby naruszał porządek społeczny do tego stopnia, iż do przywrócenia go jest konieczna represja prawna w postaci kary ${ }^{7}$.

Nie ulega też wątpliwości, że władzy społecznej, która ma prowadzić powierzone sobie społeczeństwo do wspólnego dobra i dlatego usuwać wszystkie przeszkody na drodze do tego celu, a przede wszystkim bronić porządku spolecznego, bez którego ten cel nie może być osiągnięty, przysługuje z samej natury rzeczy uprawnienie do stosowania wszystkich środków koniecznych do skutecznej obrony tego porządku społecznego, niezależnie od tego, czy te środki są uprzednio ustalone $i \mathrm{w}$ ustawie przewidziane czy też nie. Wśród tych środków niewątpliwie na pierwszym miejseu stoi kara, która ze swej istoty, jako odwet, zmierza do zadośćuczynienia społeczeństwu za szkodę przez przestępstwo mu wyrządzoną czyli do przywrócenia naruszonego porządku prawnego ${ }^{8}$.

Tak więc z punktu widzenia prawa naturalnego nic nie stoi na przeszkodzie, aby władza publiczna mogła karać czyny naruszające porządek społeczny bez uprzedniego zakazania ich w ustawie karnej. Przeciwnie nawet, prawo naturalne zdaje się dyktować postulat, który można by wyrazić w następującej zasadzie: „nullum crimen sine poena ad ordinem iuridicum restaurandum necessaria" - żadne przestępstwo nie powinno ujść bezkarnie, jeżeli ukaranie go jest konieczne do naprawienia pogwalconego porządku prawnego. Ta zasada, jako dyktat prawa naturalnego, ma charakter bezwzględny. Stąd władza publiczna powinna nawei ukarać czyn bezprawny, ilekroć jest to konieczne do przywrócenia i naprawienia porządku prwnego, chociażby takiego czynu dotąd żadna ustawa nie kwalifikowala jako przestępstwo i nie zabraniała go pod sankcją karną.

7 Por. Wernz X. F., Ius Decretalium, t. VI, Ius poenale Ecclesiae catholicae, Prati 1913, 15 ad III; Lega M., De delictis et poenis ${ }^{2}$, Romae 1910, 22-24; Latini J., Iuris criminalis philosophici summa lineamenta, Taurini-Romae 1924, 68; R oberti F., De delictis et poenis, Romae s. a., I, 47; S to c chier.o G., Diritto penale della Chiesa e dello Stato Itaiiano, Vicenza 1932, n. 43, p. 75-76; Sc h a uf H., Einführung in das kirchliche Strafrecht, Aachen 1952, n. 21; Cas s o l a O., Natura e divisione del delitto, Apollinaris 34 (1961) n. 3-4, 335; M ichiels G., De delictis et poenis ${ }^{2}$, Parisiis - Tornaci, 1961, I, 80; Pellegrini G. J., Ius Ecclesiae poenale, I, Neapoli 1962, 53-54.

${ }^{8}$ Por. Cavag $\mathrm{n}$ is F., Iinstitutiones iuris publici ecclesiastici, v. I. Romae 1882, 83 nn. i 93 nn.; Ca p pe 11 o F. M., Summa iuris publici ecclesiastici, ${ }^{6}$, Romae 1954, n. 58-64; Ottavian i A., Institutiones iuris publici ecclesiastici ${ }^{2}$, Romae 1958, I, n. 59-63; Ferrante J., Summa iuris constitutionalis Ecclesiae, Romae 1964, n. 28. 
Zdrowy rozsądek jednak dyktuje, że dla uniknięcia możliwych nadużyć w wymiarze sprawiedliwości karnej, dla utrzymania pewności $w$ porządku prawnym, tak pożądanej w życiu społecznym, jak również ze względu na funkcję prewencyjną czyli odstraszającą kary, jest rzeczą bardzo wskazaną, aby prawodawca jasno i wyraźnie określił w uprzednio głoszonej ustawie, które czyny naruszające porządek społeczny i pod jakimi warunkami należy uważać za przestępstwa i jakie za nie sprawcom grożą kary.

Jak wspomniano, kara na tyle jest usprawiedliwiona na ile jest konieczna do przywrócenia porządku prawnego, pogwałconego przez przestępstwo. W wielu bowiem wypadkach nadużyć wolności indywidualnej nie są konieczne do utrzymania i zabezpieczenia czy naprawienia tego porządku sankcje karne w ścisłym tego słowa znaczeniu, lecz wystarczą środki dyscyplinarne lub zapobiegawcze jak upomnienie, magana, nadzór itp. Czasem w ogóle interwencja władzy publicznej jest zbyteczna. $Z$ drugiej strony tak dobro spoleczne powierzone tej władzy, jak i szkodliwość społeczna poszczególnych czynów bezprawnych i konieczność karania ich sprawców nie zawsze jest jednakowo w danym społeczeństwie pojmowana. Poza tym sędziowie, choćby byli wzorowymi ludzmi pod względem moralnym, wszechstronnie wykształconymi i dobrze przygotowanymi do spełniania swego zawodu, łatwo moga ulegać różnego rodzaju wpływom naukowym, ideologicznym i politycznym, które mogá im nie pozwalać tak na obiektywną ocenę konkretnego czynu jako społecznie szkodliwego i zasługującego na karę jak również na sprawiedliwy jej wymiar. Gdy się to wszystko weźmie pod uwagę, łatwo spostrzec, do jakich nieporozumień, jak zagorzałych dyskusji i ilu nadużyć mogłoby dojść, gdyby pozostawić całkowicie swobodnemu uznaniu sędziego sąd o przestępczości i karalności poszczególnych konkretnych czynów, o ich stosunku do bardzo abstrakcyjnego pojęcia porządku społecznego i dobra publicznego, o rozmiarach zakkócenia tego porządku przez poszczególny czyn bezprawny i o konieczności wymierzenia takiej a nie innej kary w celu naprawienia naruszonego porządku prawnego ${ }^{9}$.

Poza tym kara, oprócz tzw. funkcji odwetowej czyli pomszczenia przestępstwa i zadośćuczynienia społeczeństwu za naruszenie porządku prawnego, powinna spełniać rolę prowencyjną, tzn. powinna mieć na celu odstraszenie podwładnych od popelniania przestępstw ${ }^{10}$. Cel ten jest wprawdzie drugorzędny, ale nie mniej

${ }^{9}$ Por. Wernz X. F., dz. c., n. 14 ad III, nota 11 ; M ichiels G., dz. c., I, $80-81$; C a s ol a O., art. c., 335 ; P e per on i S., dz. c. 89.

10 Por. Michiels G., De vera natura poenae, in specie ecclesiasticae, Apallinaris 32 (1959) 224; Lernel1 L., Podstawy nauki polityki kryminalnej, Warszawa 1967, $431 \mathrm{nn}$. 
ważny dla właściwej walki z przestępczością. Celu tego jednak kara nie mogłaby $w$ pełni osiągnąć, jeśliby nie była uprzednio w ustawie określona $i$ zapowiedziana, tak aby podwładni jasno z góry wiedzieli, jaka ich kara czeka za zamierzone przestępstwo 11 .

Tak więc, choć zasada: „nullum crimen nullaque poena sine lege poenali praevia" nie jest postulatem pierwszorzędnym czyli bezwzględnym prawa naturalnego, podyktowana jest jednak słusznymi racjami właściwej polityłi kryminalnej, wchodzącej w skład funkcji kierowniczych, do pełnienia których władza publiczna jest zobowiązana $z$ prawa naturalnego. Pozytywne przeto usankcjonowanie czyli ustawowe wprowadzenie jej do prawa karnego jest bardzo pożyteczne, a nawet względnie konieczne.

\section{Rozwój historyczny zasady legalności w prawie karnym}

\section{A. Prawo państwowe}

Niektórzy autorzy, zwłaszcza zwolennicy niemieckiego socjalizmu narodowego, twierdzą, że zasada legalności w prawie karnym wywodzi się $z$ prawa rzymskiego. Jednak nie wszystkie zasady prawne, mimo, że wyrażane w formułach lacińskich, pochodzą od Rzymian 12.

Otóż w rzymskim prawie karnym trzeba koniecznie rozróżnić dwie funkcje, jakie spełniali przedstawiciele władzy publicznej W odniesieniu do przestępczości podwładnych. Jedna z nich polegała na wymierzaniu kar w ścislym tego słowa znaczeniu, czyli miała charakter represyjny. Druga natomiast miała znaczenie prewencyjne i wyrażała się w stosowaniu środków policyjno-dyscyplinarnych, jak grzywna, chłosta itp. W przeciwieństwie do pierwszej, nazywanej poenitio, nosiła miano coercitionis. Pelniacy tę funkcje urzędnicy nie byli skrępowani ustawami. Mając na celu skuteczne zapobieganie przestępczości, stosowali różne środki wywierania przymusu i karcenia opornych według własnego uznania 13. Gdy zaś chodzi o wymiar kar w ścisłym znaczeniu, trzeba w rozwoju rzymskiego prawa karnego rozróżnić trzy okresy, którym odpowiadaja trzy różne rodzaje postępowania czyli procesu

11 Por. M i c hiels G., De delictis et poenis, I, 81.

12 Por. Vas s a 11 i G., dz. c., 19 i autorów tam przytoczonych; Schulz F., Prinzipien des römischen Rechts, München-Leipzig 1934, 118.

13 Por. Ferini C., Diritto penale romano, Teorie generali, Milano 1889, 40 nn.; F a $1 \mathrm{ch}$ i G. F., Diritto penale romano, I, Padova 1937, 32; M om m e n Th., Römisches Strafrecht, Graz 1955, 35 nn.; B r a s i e 110 U., La repressione penale in diritto romano, Napoli 1937, 30-32; Tenże, Diritto penale romano, Torino 1959, $2 \mathrm{nn}$. 
karnego. I tak $\mathrm{w}$ okresie tzw. procesu komicjalnego, tj. w pierwszych wiekach Republiki, kiedy to wymierzanie kar następowało na zgromadzeniach ludowych, były już wprawdzie znane pewne podstawowe formy przestępstw i odpowiednich kar ustalonych przez poszczególne ustawy, niemniej jednak trybunały ludowe mogły karać różnego rodzaju przestępstwa, w tych ustawach nie przewidziane, według własnego uznania. $Z$ chwilą zaś wprowadzenia tzw. quaestiones, czyli od połowy II w. przed Chr., tak sposób postępowania jak i rodzaje przestępstw oraz wymierzane za nie sankcje były ściśle określane przez ustawy, tak że nie bylo można karać czynu, któryby nie byl̀ $\mathrm{w}$ ustawie potępiony jako przestępstwo, względnie wymierzyć kary $w$ ustawie nie przewidzianej. W tym okresie zasada legalności w pewnym znaczeniu była u Rzymian przestrzegana 14 .

Od czasów jednak Augusta zaczyna wchodzić w życie nowa procedura karna, tzw. cognitio extra ordinem, nieskrępowana przepisami ustawowymi i pozostawiająca urzędnikom cesarskim dużą swobodę $\mathrm{w}$ karaniu przestępstw. Ten nowy proces karny $\mathrm{z}$ biegiem czasu wyparł z życia stara procedurę zwyczajną, tak że w okresie pełnego rozwoju prawa rzymskiego wymiar kar opierał się zasadniczo na swobodnym uznaniu cesarza i jego urzędników. Stosowano nie tylko analogię i szeroką interpretację ustaw, ale karano również czyny dotąd ustawowo nieokreślone jako przestępstwa i wymierzano kary tak co do rodzaju jak i co do wielkości niezależnie od ustaleń ustawowych ${ }^{\mathbf{1 5}}$.

Również $w$ systemach prawnych średniowiecznych jak i nowożytnych aż do połowy XVIII wieku nie spotykamy zasady legalności, podobnie jak nie znany byl im zakaz stosowania analogii czy szerokiej interpretacji 16 . Pewne jednak ustawowe ograniczenia dowolności sędziów $w$ karaniu przestępstw spotykamy już wcześniej. I tak w Anglii już w tzw. Magna Charta Libertatum z 1215 r. spotykamy artykuł, który postanawia, że człowiek wolny może być pozbawiony wolności, zesłany czy w jakikolwiek inny sposób karany tyiko przez legalny sąd na podstawie obowiązującej na danym terytorium ustawy ${ }^{17}$. Car zaś serbski Douchan w art.

14 D. 50, 16, 131, 1: Ulpianus 1. 3 ad legem Juliam et Papiam: „poena non irrogatur nisi quae quaque lege yel quo alio iure huic delicto imposita est". Por. Brasiello U., La repressione penale..., $21 \mathrm{nn}$. i $142 \mathrm{nn}$.

15 Por. Fer in i C., Diritto penale romano. Esposizione storica e dottrinale, Milano 1902, 9; D e M a u r o G. B., Nullum crimen, nulla poena sine praevia lege poenali, Rivista penale 102 (1925) 308 ; Schot t1 a ender A., Die geschichtliche Entwiclung des Satzes: nulla poena sine lege, Breslau 1911, 4 i 6; M om m e n Th., dz. c., 251 nn.; B r as i e 11 o U., dz., c., 44.

${ }_{16}$ Por.' Vas a alli G., dz., c., 26 nn.

17 "Nullus liber homo capiatur vel impresonetur aut dissaisiatur aut 
172 swego kodeksu karnego z 1349 r. nakazuje: „Niech sędziowie sadzą wedlug kodeksu dokiadnie jak jest $w$ nim napisane, a nie dla wywołania strachu przede mną..." Również w polskim starym prawodawstwie, począwszy od Władysława Jagiełły, ściśle mówiąc od r. 1433, często ustawy królewskie podkreślają, że nikt nie może być skazany, jeśli mu się prawnie nie dowiedzie przestępstwa is.

Ideę legalności zawarta w dzisiejszej formule: „Nullum crimen nullaque poena sine lege poenali praevia" przygotowali penaliści włoscy XVII w. Spotykamy u nich zdania, które całkowicie się $z$ tą zasadą pokrywają. I tak np. Wincenty Carocius uczy: „nie każdy czyn niegodziwy jest przestępstwem..., lecz tylko ten, który ustawa określa jako karalne przestępstwo". Podobne zdanie wygłasza Jan Zuffus: ,gdzie nie ma kary ustalonej przez prawo, tam nie ma przestępstwa, chociażby czyn byl bezprawny". To samo łwierdzi Prosper Farinasius, słynny penalista owych czasów: „nie każdy czyn bezprawny jest karany, lecz tylko ten, który w ustawie jest uznany za przestępstwo" 19.

Tę naukę jeszcze bardziej rozwinęli filozofowie polityczni XVIII w., mianowicie Monteskiusz, Pufendorf i Rousseau. I tak Monteskiusz w dziele ,O duchu praw”, szukając gwarancji dla wolności politycznej obywateli, głosi teorię całkowitego rozdziału potrójnej funkcyjnie władzy publicznej: ustawodawczej, wykonawczej i sądowej. Ten podział ma ograniczyć samowolę i możliwe nadużycia piastunów poszczególnych władz. Granice władzy sądowej w myśl zasady legalności wyraża tymi słowy: ,sędziowie narodu to są... jedynie usta, które wyglaszają brzmienie praw" 20. W ten sposób Monteskiusz, choć nie używa formuly przyjętej dziś do określenia zasady legalności, stał się jednaik zdecydowanym rzecznikiem tej zasady w XVIII w., gdyż wynika ona z calej jego konstrukcji podziału władzy państwowej jak również z jego koncepcji sądownictwa, które powinno realizować, a nie tworzyć prawa ${ }^{21}$.

utlegatur aut exuletur aut aliquo modo destruatur nec super eum ibimus nec super cum mittemus nisi per legale iudicium parum suorum vel per legem terrae" - przytaczam za V as s alli G., dz., c., 35.

18 Por. V a s a 1 i i G., dz., c., 36.

19 C a r ocius Vinc., Tractatus varii, Venetilis 1603: „Non Omne quad illicitum est delictum est.. nisi lex declaravit delictum punibile". $Z$ u f$f u s$ Joannes, Tractatus de criminalis processus legitimatione, Romae 1665, s. 70: „Ubi non cadit poena a iure expressa ibi delictum non est, etiam quod illud sit illicitum"; F a $\mathrm{r}$ in a ci us Prosper, Praxis et theoricae criminali pars $I$, t. I, Venetiis 1609, p. 155: "Non omme illicitum punitur sed illud demum, quod lex statuit esse delictum". Por. V as s ali G., dz. c., $30 \mathrm{nn}$.

20 M onteskiusz, O cuchu praw, Warszawa 1957, t. I, 243.

21 Por. Pławski S., Zagadnienia prawa karnego $w$ dzielach Monteskiusza, w: Monteskiusz i jego dzieło, Warszawa 1956, 158. 
Pufendorf i Rousseau gloszą tzw. Balanciertheorie, wedlug której zadaniem kary jest ukazać obywatelom, że ona swym ciężarem czyli dolegliwością i stratą, jakie za sobą pociąga, przeważa korzyści oczekiwane $z$ pogwałcenia prawa. W myśl tej teorii podwładni z góry powinni wiedzieć, jaka im kara grozi w wypadku popełnienia określonego przestępstwa. Dlatego konieczny jest dokladny i wyczerpujący katalog ustawowy przestępstw i grożących za nie sankcji karnych, wyłączający jednocześnie zwyczaj jako źródło norm karnych, analogię i szeroką interpretację obowiązujących już ustaw 22.

Postulaty wysuwane przez włoską naukę prawa karnego i przez wspomnianych pisarzy politycznych wkrótce zostały przyjęte we współczesnych ustawodawstwach. Tak np. cesarz austriacki Józef II w swym kodeksie karnym z 1787 r. postanawia: „Nie każdy czyn przeciwny prawu jest przestępstwem lub zbrodnią. Za przestępstwo kryminalne należy uważać tylko te czyny bezprawne, które w tym kodeksie są określone jako przestępstwa (I § 1). Sędzia karny jest zobowiązany do ścisłego przestrzegania wszystkiego, co ustawa wyraźnie określa, czy to $\mathrm{w}$ odniesieniu do samego przestępstwa, czy też do rodzaju i miary kary" (I § 13) 23. Taką samą zasadę wprowadza francuska deklaracja praw czlowieka i obywatela z roku 1789 (art. 7) oraz ustawa konstytucyjna $z$ r. 1791, w której czytamy: "Nikt nie może być karany jak tylko na podstawie ustawy ustanowionej i ogłoszonej przed popełnieniem przestępstwa $\dot{1}$ legalnie do niego zastosowanej" (art. 8) 24. Za prawodawstwem francuskim poszedl pruski kodeks karny z $1794 \mathrm{r}$., który postanawia: „Czyny lub zaniechania, które nie są zakazane w ustawie pod groźba kary, nie moga byé uważane za prawdziwe przestępstwa" (§ 7 II, 20) 25.

Stopniowo zasada legalności przyjmowała się w nastẹpnych kodyfikacjach prawa karnego, tak ze dziś panuje prawie we wszystkich ustawodawstwach karnych 26.

Gdy zaś chodzi o ujęcie zasady legalności w przyjętą dziś powszechnie formułę: "nullum crimen, nulla poena sine lege", to

22 Pufendorf S., De iure naturae et gentium, Londini 1672, 1. VIII, c. III, $\S 12$, p. 1063 ; R a us s e u J. J., Du contrat social, Paris 1955, 96; Por. Michiels G., De delictis et poenis, I, 79, nota 2.

${ }_{23}$ Allgemeines Gesetz über Verbrechen und derselben Bestrafung, Wien 1787. Por. Sa $1 \mathrm{~m}$ o n o w i c S., Prawo karne oświeconego absolutyzmu. Z dziejów kodyfikacji karnych przełomu XVIII/XIX w., Toruń 1966,90 .

${ }_{24}$ Por. Vas s a 11 i G., dz. c., 39-40. Jeszcze mocniej podkreśla tę zasadę konstytucja z 24. VI. 1793 r. Zob. tamże.

${ }_{2 \check{0}}$ Allgemeines Landrecht für die Preussischen Staaten, Berlin 1832. Por. S a $1 \mathrm{~m}$ on ow i c z S., dz. c., 216 i 221.

${ }_{26}$ Por. V a s a 11 i G., dz. c., 40. 
spotyka się ją po raz pierwszy u niemieckiego penalisty Feuerbacha 27 .

\section{B. Prawo kanoniczne}

W kościelnym prawie przedkodeksowym nie znajdujemy wyraźnego sformułowania ustawowego zasady legalności karnej. Niektórzy kanoniści stawiają wprawdzie tezę przeciwną i starają się jej dowieść pewnymi tekstami źródłowymi, ale przytaczane przez nich teksty wyrażaja raczej zakaz stosowania analogii względnie szerokiej interpretacji $\mathrm{w}$ prawie karnym, a nie zasade legalności w ścisłym znaczeniu 28.

Praktyka jednak i nauka prawa kanonicznego skłaniała się stopniowo do tego, by nie karać czynów bezprawnych bez uprzedniego zagrożenia sankcją karna, wyrazonego czy to w ustawie, czy téz $w$ nakazie administracyjnym. Początkowo bowiem jakiekolwiek ciężkie wykroczenie przeciwko prawu kanonicznemu mogło być karane nie tylko w zakresie wewnętrznym - in foro interno - jako grzech, lecz również w zakresie zewnętrznym, ze względu na zakłócenie kościelnego porządku społecznego. Nie było przecież żadnego wyczerpującego katalogu przestępstw zagrozonych z góry odpowiednimi sankcjami karnymi. Wymiar kar przez długi okres czasu zależał $w$ dużej mierze od roztropnego uznania sędziego. Stąd przyjęly się w starym ustawodawstwie kościelnym tzw. kary nadzwyczajne $i$ arbitralne. $Z$ biegiem czasu jednak rozwijał się system kościelnego prawa karnego i coraz dokładniej w konstytucjach papieskich czy uchwalach soborowych były określane poszczególne przestępstwa i odpowiadające im kary. W ten

${ }^{27} \mathrm{Fe}$ e e $\mathrm{rbach} \mathrm{A}$, Lehrbuch des gemeinen in Deutschland gultigen peinlichen Rechts, 14a, Giesse $1847, \S 20$, s. 41. Por. V a s s a 11 i G., dz. c., $41 \mathrm{i}$ n.; S a $1 \mathrm{~m}$ on o w i cz S., dz. c., 35, przyp. 66.

${ }_{28}$ Tak np. doszukuja sie śladów tej zasady $w$ starym prawie kanonicznym: Katz E., Grundriss des canonischen Starfrechts, Berlin 1881, S. 3, n. 3; Heiner F., Katholisches Kirchenrecht, Paderborn 1893, II. 82; Hollweck I., Die kirchliche Strafgesetze, Mainz 1899, 66, nota 5; Gi a c chi O., Precedenti canonistici del principio - nullum crimen sine praevia lege poenali, w: Studi in onore di F. Scaduto, Firenze 1936, I, 437 i nn.; Lopez de On at e P., La certezza del diritto, Roma 1942, 45. Przeciwnego zaś zdania są: $\mathrm{K}$ a h n L.,Etude sur le délit et la peine en droit canonique, Nancy 1898,33 ; H in sch i u s P., System des katholischen Kirchenrechts, IV, Berlin 1888, 745, nota 4; V, Berlin 1895, 663, nota 5 i 906-907; S chia p poli D., Diritto penale canonico, Milano 1905, n. 42; Wernz X. F., dz. c., VI, n. 14 ad III; H o h enlohe C., Beitrage zum Einflüsse des kanon. Rechts auf Strafrecht, Wien 1918, 21 i nn.; Fedele P., Introduzione allo studio del diritto canonico, Padova 1963, 222 n.; Tenże, Lo spirito del diritto canonico, Padova 1962, 222 i 775 i nn. 
sposób przyjął się więc zwyczaj karania tylko tych czynów bezprawnych, które były wyraźnie zakazane pod groźbą kary w ustawie lub w nakazie kompetentnego przełożonego. W oparciu zaś o tę praktykę rozwinęla się nauka kanonistów stawiająca zasadę, że normalnie nie należy poczytywać za przestępstwo i karać czynu niegodziwego, którego nie zabrania wyraźnie ustawa kościelna lub zakaz przelożonego pod sankcją kary, chyba że w szczególnym wypadku naruszenie porządku prawnego jest tak wielkie, íz dobro publiczne domaga się ukarania jego sprawey ${ }^{29}$. Po tej myśli poszedł też Kodeks prawa kanonicznego.

\section{Zasada legalności w Kodeksie prawa kanonicznego}

Kodeks prawa kanonicznego nie wypowiada wprawdzie wyraźnie przyjętej formuły wyrażającej zasadę legalności karnej, jednak zasada ta nie jest mu obca. I tak w kan. $2195 \S 1$, podając praktyczną definicję przestepstwa, stanowi: „Pod nazwa przestępstwa rozumie się w prawie kościelnym zewnętrzne i moralnie poczytalne pogwalcenie ustawy, które jest zagrożone sankcją kanoniczną, przynajmniej nieokreśloną" ${ }^{30}$. Z tego określenia jasno wynika, że Kodeks prawa kanonicznego przyimuje zasadę legalności $W$ prawie karnym. W myśl bowiem tego kanonu za przestępstwo może uchodzić tylko takie przekroczenie ustawy kościelnej, które uprzednio jest zagrożone sankcją karną, choćby bliżej nie określoną. Taki wniosek potwierdza kan. $2220 § 1$, który stanowi, że ci, którzy w Kościele piastują jedynie władzę sędziowską, mogą tylko stosować zgodnie z obowiązujacym prawem kary juz prawnie ustalone 31 .

Myliłby się jednak bardzo, ktoby na podstawie przytoczonych kanonów sądzil, że Prawodawca kościelny przyjmuje zasadę legalności tak bezwzględnie i rygorystycznie, jak ją się pojmuje we współczesnych ustawodawstwach państwowych. Dokładniejszy bowiem rozbiór kanonów dotyczących tego zagadnienia wskazuje na to, że ta zasada w prawie kanonicznym odznacza się dużą elastycznością.

Przede wszystkim należy zauważyć, że w kościelnym prawie karnym przestępstwem może być przekroczenie nie tylko ustawy, powszechnej czy partykularnej, lecz także rozkazu karnego wydane.-

${ }^{29}$ Por. D'Annibale J., Summula Theologiae moralis 5 , I, Romae 1908, 296; Holl we ck I., dz. c., 65-66; Mich iels G., dz. c., 79-80; Ca se y J., A study of can. $2222 \& 1$, Washington, 1949, 6 nn. i 23 nn.

${ }^{30}$ Can. $2195 \& 1$ : ,Nomine delicti, iure ecclesiastico intelligitur externa et moraliter imputabilis legis violatio cui addita sit sanctio canonica saltem indeterminata".

31 Can. $2220 \S 1$ : ,...qui iudiciali tantum (potestate pollent) possunt solummodo poenas, legitime statutas, ad normam iuris applicare". 
go przez kompetentnego przełożonego. Mówi o tym wyraźnie kan. 2195 § 2: „Jeżeli z okoliczności nic innego nie wynika, przepisy dotyczące przestępstw stosuje się również do pogwałcenia rozkazu obwarowanego sankcją karną" 32 .

Następnie trzeba zwrócić uwagę na to, że do karalności jakiegoś czynu bezprawnego, czyli do poczytania go za przestępstwo i wymierzenia sprawcy odpowiedniej kary, wcale w myśl oma wianego kanonu $2195 \& 1$ nie jest rzeczą konieczną, aby zagrożenie sankcją karną zawierało się w tej samej normie prawnej, która dany czyn lamie. Kanon bowiem wymaga tylko, by samo pogwałcenie prawa było obłożone karą - legis violatio cui addita sit cancio canonica -, chaciażby samą sankcję ustanawiała i nakładała zupełnie inna norma. Taki jest wprawdzie normalny sposób postępowania wladzy kościelnej i zasadniczo tą myślą kieruje się Prawodawca kościelny $\mathrm{w}$ redakcji analizowanego kanonu, zakładając mianowicie, że $z$ reguły uważa się za przestępstwo tylko naruszenie takiej normy prawnej, która zawiera w sobie sankcję karną, czyli jakiś nakaz lub zakaz pod groźbą kary. Przewiduje jednak Kodeks w drugiej części kan. $2222 \S 1$ takie wypadki, w których przekroczenie prawa kościelnego należy traktować W myśl omawianego kanonu 2195 jako prawdziwe przestępstwo, chociaż pogwałcona norma nie zawiera w solbie wzmianki o karze, czyli sama w sobie jest normą czysto dyscyplinarna, byleby jej pogwałcenie było uprzednio zagrożone karą. Zachodzi to mianowicie wtedy gdy przełożony kościelny, chcąc zapobiec w jakimś konkretnym wypadku pogwał̌ceniu przepisu prawnego czysto dyscyplinarnego, stosuje tzw. upomnienie kanoniczne - monitionem canonicam -, grożąc podwładnemu, w wypadku wykroczenia przeciwko temu przepisowi, pewną sankcją karną, a ten mimo upomnienia dany przepis przekracza.

Praktycznie więc biorąc, można powiedzieć, że w prawie kanonicznym może być w konkretnym wypadku poczytane za prawdziwe przestępstwo przekroczenie jakiejkolwiek ustawy czy rozkazu, byleby ono było uprzednio zagrożone sankcją karną, zawartą w samej normie $w$ danym wypadku pogwałconej, czy też $\mathrm{w}$ upomnieniu przełożonego, przestrzegającego przed naruszeniem normy czysto dyscyplinarnej. $Z$ tego więc wynika, że kościelne prawo karne zamiast zasady: „Nullum crimen, nulla poena sine lege poenali praevia" przyjmuje raczej zasadę bardziej elastyczną: „nullum crimen nullaque poena sine sanctione poenali praevia" 33 .

32 Can. $2195 \S 2$ : „Nisi ex adiunctis aliud. appareat, quae dicuntur de delictis, applicantur etiam violationibus praecepti cui poenalis sanctio adnexa sit". Por. P e p e r o n i S., dz. c., 95.

${ }^{33}$ Por. Cas ey J., dz. c., 38-40; M i ch i e $1 \mathrm{~s} \mathrm{G.,} \mathrm{dz.} \mathrm{c.,} \mathrm{83.} \mathrm{Pell} \mathrm{e-}$ grin i G. J., Iius Ecclesiae poenale, I, 54. 
Ponadto trzeba podkreślić, że kan. $2195 \S 1$ wyraźnie zaznacza, iż dlatego, aby jakąś normę prawa kościelnego można było uważać za karną, a jej przekroczenie za przestępstwo, wcale nie jes: wymagana kara ściśle określona, czyli w ustawie lub nakazie kościelnym dokładnie co do rodzaju i wielkości ustalona i niepozostawiająca sędziemu możliwości zmodyfikowania jej. Wystarczy bowiem sankcja karna bliżej nie oznaczona, tzn. taka, której wybór lub wymiar jest pozostawiony roztropnemu uznaniu sędziego lub przełożonego. Faktycznie w V księdze Kodeksu prawa kanonicznego spotykamy różnego rodzaju oznaczenia kar, już to ograniczające, już to mniej lub więcej rozszerzające swobodę sędziego lub przełożonego. W wielu wypadkach Prawodawca kościelny dokładnie określa karę przewidzianą za poszczególne przestępstwa, w innych zaś podaje tylko skrajne granice, tzn. karę największą i najmniejszą, pozostawiając wybór sędziemu. Kiedy indziej znów nakazuje wymierzyć odpowiednią karę według roztropnego uznania sędziego. Czasem mówi poprostu, że kara powinna być wymierzona według wielkości winy sprawcy. W niektórych wypadkach upoważnia tylko sędziego lub przelożonego do nałożenia jakiejś kary, uzależniając od ich uznania nie tylko wybór kary, ale i decyzję, czy karać czy też nie. Przyznać więc trzeba, że Kodeks pozostawia sędziemu dużą swobodę w wymiarze kar, polegając na jego roztropnym uznaniu ${ }^{34}$.

Na podstawie więc przytoczonych kanonów 2195 i 2222 § 1 należałoby sądzić, że zasadę legalności tak elastycznie pojętą: „Nullum crimen nullaque poena sine sanctione poenali praevia saltem indeterminata" Kodeks prawa kanonicznego przyjmuje całkowicie, tak że żadne zewnętrzne pogwałcenia prawa kościelnego nie może być poczytane za przestępstwo i karane w zakresie zewnętrznym, jeżeli nie było ono uprzednio oblożone jakąś sankcją karną, chociażby bliżej nie określoną.

Temu jednak stwierdzeniu zdaje się przeczyć inna norma cytowanego kanonu $2222 \S 1$, która stanowi: ,chociaż ustawa nie jest obłożona sankcją karną, kompetentny jednak przełożony może za jej pogwałcenie, nawet bez uprzedniego zagrożenia kara, wymierzyć jakąś słuszną karę, jeżeli ewentualne zgorszenie lub niezwykle wielka bezprawność czynu tego wymaga" ${ }^{35}$. W skutek tego w kanonistyce panuje duża rozbieżność zdań na temat stosunku

${ }^{34}$ Por. Michiels G., dz. c., 84; Roberti F., De delictis et poenis, I, 75.

${ }_{35}$ Can. 2222 \& 1: ,Lecet lex nullam sanctionem appositam habeat, legitimus tamen Superior potes illius transgressionem, etiam sine praevia poenae comminatione, aliqua iusta poena punire, si scandalum forte datum aut specialis transgressionis granitas id ferat...". Por. MI ichiels G., Normae generales, I, 247; De delictis et poenis, I, 84. 
tego przepisu do kanonów wyżej omawianych, które zda ‘ą się zakładać, iż system kościelnego prawa karnego opiera się na zasadzie legalności.

Wypowiedzi kanonistów na ten temat dadzą się sprowadzić do czterech głównych opinii.

a) I tak wedlug jednych Kodeks prawa kanonicznego przyjmuje zasadę legalności w całej jej pełni. Przytoczone wyżej kanony zgadzają się według tych autorów $\mathrm{w}$ tym sensie, że kanon 2195 mówi o przestępstwie w ścisłym tego słowa znaczeniu i odnosi się do wszystkich przestępstw w Kodeksie przewidzianych, a kanon 2222 $\S 1$ dotyczy wykroczeń przeciwko prawu kościelnemu, które nie stanowia przestępstw $w$ ścisłym znaczeniu, lecz są tylko w prawie do nich przyrównane. W Kościele jako społeczności, której podział władzy, właściwy spolecznościom państwowym, jest obcy, a nawet $z$ ustanowienia Bożego nie może mieć miejsca, uprawnienie nadane przełożonym na podstawie kan. $2222 \S 1$ jest słuszne i konieczne $\mathbf{3 6}^{\mathbf{6}}$.

W odniessieniu do tej opinii należy zauważyć, że nie ma dostatecznych podstaw do rozróżniania między przestępstwami w ścisłym znaczeniu, które określa kan. 2195 i wypadkami przekroczenia prawa kościelnego przewidzianymi w kanonie $2222 \S 1$ nie stanowiącymi rzekomo przestępstwa. Jeżeli bowiem ma miejsce naruszenie przepisu prawnego, za które można wymierzyć karę w ścisłym znaczeniu, to w jaki sposób i na jakiej podstawie można tego rodzaju pogwałceniu prawa odmawiać charakteru przestępstwa? Ustawodawca kościelny we wspomnianym kanonie $2222 \S 1$ wyraźnie przecież mówi o wymierzeniu pewnej słusznej kary (aliqua iusta poena punire), nie czyniąc żadnego zastrzeżenia, jako np. ma miejsce w $\S 2$ tegoż kanonu, w którym wyraźnie jest zaznaczone, że $\mathrm{w}$ danych wypadkach nie chodzi o karę w ścisłym tego słowa znaczeniu. Tak więc ta koncepcja wcale nie prowadzi do pogodzenia wymienionych kanonów i utrzymania w mocy zasady legalności, pojętej w sposób bezwzględny, jak się to wydaje autorom tej opinii. Przekraczający bowiem ustawę nie oblożoną uprzednio sankcją karną dzieli faktycznie los przestępcy, co właśnie sprzeciwia się zasadzie legalności ${ }^{37}$.

b) Wielu autorów twierdzi, że w przytoczonych słowach kan. $2222 \S 1$ zawiera sị wyraźny wyjątek od zasady legalności, na którą wskazują kan. 2195 i $2222 \S 1$ - w drugim zdaniu, tak że według tych autorów $w$ wypadkach przewidzianych w tym ka-

${ }^{36}$ Tak np. Vermeersch-Creusen J., Epitome iuris canonici, Mechliniae 1928, III, 184. W VI jednak wydaniu z r. 1946 opinia ta została znacznie zmieniona, tak że raczej pokrywa się z następną teoria, omówioną niżej pod b.

${ }^{37}$ Por. Roberti F., dz., c., I, 70-71; P eperoni S., dz., c., 90. 
nonie jest dopuszczalne karanie ustawy kościelnej czysto dyscyplinarnej tzn. nie obwarowanej żadną sankcją karną ${ }^{38}$.

W związku z tą opinią F. Roberti stara się wykazać, że w tym wypadku nie można pogodzić zasady z wyjątkiem: Jego zdaniem zasada: „nullum crimen sine lege etc." tylko wtedy ma sens jeżeli się ją przyjmie i utrzyma w całej rozciąglości - bez żadnego wyjątku. Stad pojmowanie przepisu kan. $2222 \S 1$ jako wyjatek od reguły wyrażonej w kan. 2195 całkowicie przekreśla zasadę legalności w tym kanonie zawartą ${ }^{39}$.

Zdaniem S. Peperoni'ego zastrzeżenie to nie jest sluszne. Przepis bowiem kan. $2222 \S 1$ pojęty jako wyjątek do kan. 2195 według tego autora nie niweczy całkowicie zasady legalności, lecz najwyżej ją w pewnym stopniu łagodzi. Wyjątek zawarty w tym kanonie nie jest przecież nieograniczony, tak żeby całkowicie zaprzeczal tej zasadzie, lecz odnosi się tylko do dwóch określonych wypadków, mianowicie: gdy ma miejsce zgorszenie lub niezwykle wielkie pogwalcenie prawa kościelnego (si scandalum forte datum aut specialis transgressionis gravitas id ferat). Okoliczności te są wprawdzie określone w tym kanonie bardzo ogólnie, nie dopuszczają jednak zbyt daleko idącej arbitralności. Owszem, stosując ścisłą i słuszną interpretację tego przepisu trzeba przyznać, że wprowadza on ograniczenie zasady legalności, nie można się jednak zgodzić na to, że ją całkowicie pozbawia mocy. Ograniczenie to zreszta całkowicie odpowiada zdaniem autora duchowi Kościoła, podczas gdy rygorystyczne zastosowanie zasady legalności jest mu raczej obce ${ }^{40}$.

$38 \mathrm{~S}$ ole J., De delictis et poenis, Romae 1920, n. 6 i 85 ; Chelodi I., Ius canonicum de delictis et poenis ${ }^{5}$, Vicenza 1943,.n. 2; F a l c o M., Introduzione allo studio del Codex J. C., Milano 1921, 240; S a l u c c i R., Il diritto penale secondo il Codice di diritto canonico, Subiaco 1926, I, 105 n.E i c hm a n n E. M örs dor t K., Lehrbuch des Kirchenrechts, Paderborn 1960, III, 30; $\mathrm{P}$ e peroni S., Lineamenta iuris poenalis canonici, 94. Cassola O., De applicatione poenarum ad modum pracepti, w: Miscellanea in mem. Petri Card. Gasparri, Apollinaris 33 (1960) 238. Tenże, De iure poenali Cadicis canonico emendando, Apollinaris 32 (1959) 249; Scheuermann A., Erwägungen zur kirchlichen Strafrechtsreform, Archiv für katholisches Kirchenrecht 131 (1962) 407 i n.; IM a y G., Das geistliche Wesen des kanonischen Rechts, Archiv für katolisches Kirchenrecht 130 (1961) 22; H u izing P., Delikte und Strafen, Concilium 3 (1967) 659 ; $\mathrm{H}$ of man n K., Das Verwaltungsstrafverfahren im kanonischen Recht, w: Festschrift für U. Stutz, Stuttgart 1938, 477; Jombart E., L'exercice dans l'Eglise du pouvoir administratif et $d u$ pouvoir judiciaire, Revue de Droit Cannonique 5 (1955) 334; H e r $\mathrm{rm}$ a n $\mathrm{H}$., Erwägungen zu einer Revision des c. 2222 c., 6 i 9. Por. tez V itale A., Contributo ad una teoria delle sanzioni nell'ordinamento canonico, Ephemerides Iuris Canonici 18 (1962) 282 i nn.

39 R oberti F., dz. c., 71 .

${ }^{40}$ Por. Peperoni S., dz., c., 91. 
Moim zdaniem, logicznie biorąc, należałoby przyznać rację F. Roberti'emu. Zasada bowiem legalności, przyjęta nawet w przytoczonej wyżej formie elastycznej: „nie ma przestępstwa nie ma kary bez uprzedniej sankcji karnej przynajmniej nie określonej", ma charakter zasady bezwzględnego jej brzmienia - nullum, nulla... a więc bez wyjątku. Inna zaś jest sprawa, czy ona w swej postaci bezwzględnej odpowiada duchowi prawa kanonicznego, czy też nie. Tu nam chodzi tylko o stwierdzenie, czy prawodawca kościelny ją faktycznie w kodeksie przyjmuje.

c) Inni natomiast utrzymują, że w prawie kodeksowym zawsze do poczytania jakiegoś czynu bezprawnego za przestępstwo jest konieczna jakaś sankcja karna. Normalnie w myśl kan. 2195 wymaga się sankcji uprzedzającej przekroczenie prawa. Wyjątkowo jednak, mianowicie w wypadkach wymienionych w kan. $2222 \S 1$, wystarczy sankcja następująca po przekroczeniu ustawy kościelnej, czyli zawarta w samym fakcie wymierzenia kary przez przełożonego. Według tych autorów między kan. 2195 i $2222 \S 1$ nie zachodzi stosunek podporządkowania, lecz przyporządkowania, tzn. nie ma tu reguly i wyjątku, lecz każdy $z$ tych kanonów stanowi regułę we własnym zakresie: pierwszy $\mathrm{w}$ odniesieniu do pojęcia przestępstwa, a drugi $w$ odniesieniu do władzy przełożonego. Innymi słowy kan. 2195 podaje określenie przestępstwa. Kan. zaś $2222 \S 1$ przyznaje przełożonym kościelnym władzę zagrażania w określonych warunkach sankcją karną ze skutkiem wstecznym W ten sposób przepis tego kanonu jest szczególnym wypadkiem zastosowania zasady wsteczności ustawy karnej. Tak więc akt przełożonego, wymierzającego karę w wypadkach tym kanonem przewidzianych, tzn. w wypadku gorszącego lub specjalnie ciężkiego wykroczenia przeciwko ustawie kościelnej, miałby charakter nie tylko aktu egzekucyjnego, lecz równocześnie ustawodawczego. Tym bowiem aktem przełożony, na podstawie władzy $w$ tym kanonie mu udzielonej, ustanawiałby po fakcie dokonanego pogwalcenia prawa sankcję karną, któraby swoją mocą wiążącą sięgała wstecz, aż do momentu samego dokonania czynu, zmieniając tym samym ustawe czysto dyscyplinarną na karną. Taką interpretację zdaje się podsuwać sam przepis kan. $2222 \S 1$, który wspomniane uprawnienie przyznaje tylko przełożonemu, a nie sędziemu: przełożonemu bowiem, a nie sędziemu może przysługiwać władza ustawodawcza. Zwolennicy tej koncepcji wyjaśniają ponadto, że taka interpretacja wcale nie uwlacza sprawiedliwości, jakby się to na pierwszy rzut oka wydawało. Jeżeli bowiem nie sama norma postępowania, lecz tylko zagrożenie sankcją karną ma moc wsteczną, to ukaranemu sprawcy czynu dokonanego przed zagrożeniem nie dzieje się żadna krzywda, gdyż w myśl kan. 2202 § 2 niezna-

18 - Prawo kanoniczne 
jomość kary nie znosi poczytalności karnej, lecz tylko ją w pewnym stopniu zmniejsza $\mathbf{4 1}$.

Pod adresem tej teorii należy stwierdzić, że karanie czynu naruszającego przepis ustawy nie obłożonej sankcją karną na podstawie późniejszego zagrożenia karnego, któremu się nadaje moc wsteczną, oznacza z punktu widzenia polityki kryminalnej to samo, co karanie bez uprzedniej ustawy karnej czyli wbrew zasadzie legalności. Konsekwentnie rzecz biorąc, kan. $2222 \S 1$, który według tej koncepcji jest zastosowaniem zasady wsteczności normy karnej, nie jest niczym innym jak wyjątkiem w stosunku do kan. 2195, który wyraża zasadę przeciwną, czyli niewsteczności ustawy karnej. Wobec czego opinia ta, nic nowego nie wnosi, gdyż praktycznie pokrywa się $z$ opinią poprzednią 42 .

d) Inni znów są zdania, że przepis kan. $2222 \S 1$ wcale nie jest sprzeczny $\mathrm{z}$ zasadą ogólną, wyrażoną $\mathrm{w}$ kan. 2195. Również bowiem i w wypadkach wskaznych w kan. 2222 § 1 ma miejsce uprzednie zagrożenie sankcją karną, tak że zasada legalności nie zna w kanonicznym prawie karnym żadnych wyjątków. Kodeks bowiem prawa kanonicznego nie wymaga do poczytania jakiegoś czynu bezprawnego za przestępstwo, aby sankcją karną był obwarowany ten przepis karny, przeciwko któremu dany czyn występuje. Sankcja karna może równie dobrze zawierać się w innej bardziej ogólnej normie, która odnosi się i swoją mocą wiążącą obejmuje przekroczenia całego szeregu różnych przepisów prawnych. To właśnie zachodzi w kan. $2222 \S 1$. Na podstawie bowiem tego kanonu każdy przepis prawa kościelnego, nawet taki, w którym nie ma żadnej wzmianki o karze za jego przekroczenie, należy uważać w wypadku specjalnie ciężkiego lub gorszącego wykroczenia przeciwko niemu za normę karną czyli obłożoną uprzednio pewną sankcją nieoznaczoną, której określenie w konkretnym wypadku należy do przełożonego wymierzającego ją. Innymi słowy, każde gorszące lub bardzo ciężkie naruszenie jakiegokolwiek przepisu prawa. kościelnego stanowi $w$ prawie kanonicznym prawdziwe przestępstwo, za które na mocy kan. $2222 \S 1$ grozi fakultatywna sankcja karna bliżej nieokreślona. Stąd akt przełożonego, który w takich konkretnych wypadkach karę nakłada; nie jest aktem ustawodawczym o mocy wstecznej, lecz zwykłym aktem wy.ko-

41 Tak np. Cicognani H., Ius canonicum, Romae 1925, II; 87; D'A ng elo S., Nozione de delitto nel Codex I. C., w: Saggi su questioni giuridiche, Torino 1928, $101 \mathrm{nn}$; Tenże: Retroattivitá della lege in materia penali ecclesiastica, Il Diritto Ecclesiastico 23 (1922) $143 \mathrm{nn}$. Por. P eperoni S., dz., c., 92 ; M i chiels G., Normae generales, I, $247 \mathrm{n}$.

${ }_{42}$ Por. Michiels G., dz., c., I, 248; Roberti F., dz., c., 73; Fede le P., Lo spirito..., 810; P e peroni 
nawczym ${ }^{43}$. Tak więc według tego poglądu Kodeks prawa kanonicznego podtrzymuje zasadę legalności w całym jej zakresie, tzn. w odniesieniu do wszystkich czynów karalnych w prawie kościelnym. Stosuje w prawdzie tę zasadę nie tak rygorystycznie jak współczesne ustawodawstwa państwowe, ale w granicach zupełnie wystarczająco odpowiadających postulatom słusznej polityki kryminalnej i właściwemu wymiarowi sprawiedliwości karnej. Prawodawca kościelny zdaje się zajmować stanowisko pośrednie między skrajnym legalizmem w prawie karnym, który zbytnio krępuje sędziego w wymierzeniu kar, a przesadnym liberalizmem w pojmowaniu $i$ wykonywaniu władzy sędziowskiej. Stawia bowiem zasadę, że normalnie uważa się za przestępstwa karne tylko przekroczenia norm karnych, tych mianowicie, które zawierają w sobie sankcję karną. Pozwala jednak przełożonym, ilekroć dostrzegą niebezpieczeństwo grożące porządkowi prawnemu na skutek pogwałcenia ustaw czysto dyscyplinarnych, stosować upomnienia karne i obwarowywać w nich sankcjami zagrożone przepisy prawa kościelnego. Poza tym, mając na uwadze wypadki nadzwyczajne, ustanawia ogólnie fakultatywną sankcję karną bliżej nie oznaczoną, ktọ́ra odnosi się do wszystkich wypadków specjalnie ciężkiego lub gorszącego wykróczenia przeciwko jakiemukolwiek przepisowi prawa kanonicznego.

Ujmując zasadę legalności w prawie karnym tak elastycznie, $z$ jednej strony zabezpiecza się dostatecznie przed ewentualnymi nadużyciami w karceniu wykroczeń przeciwko prawu kościelnemu, które zwykle mają miejsce w wypadku przyznania sędziemu zbyt szerokiej swobody w ocenie czynów bezprawnych i w określaniu za nie kar, a $z$ drugiej strony, mając na uwadze zasadę prawa naturalnego: Nullum crimen sine poena ad ordinem iuridicum restaurandum necessaria, wyraża troskę o to, aby w wypadkach nadzwyczajnych nie uchodziły bezkarnie, a wskutek tego z niemałą szkodą dla porządku prawnego i dobra publicznego, pogwałcenia kościelnych ustaw dyscyplinarnych, co by właśnie miało miejsce, gdyby zasada legalności była przestrzegana zbyt rygorystycznie. Ustanawiając zaś dla tych wypadków sankcję nieoznaczoną zapewnia przełożonemu dostateczną swobodę, nieod-

${ }^{43}$ Por. Vidal P., Notio delicti in iure codicis, Ius pontificium 2 (1922) 101; W e rn X. F., Vidal P., Ius canonicum², VII, Romae 1951, n. 34; R oberti F., dz. c., I, 73-76; C on te d a C or on a t M., Pene e sanzioni canoniche estragiudiziali, Torino 1933, 11; Institutiones iuris canonici ${ }^{4}$, Taurini-Romae 1955 , IV, n. 1638; B e r utti Ch., Institutiones iuris canonici, VI, Taurini-Romae 1938, s. 75 ; M i ch iels G., De delictis et poenis, I, 85 n.; C a s e y J., dz. c., 50-56. Li u z i F. A., Diritto penale canonico e diritto secolare, w: La Cassazione Penale, 1946, n. 1-4; Pog g i s p a 11 a F., La certezza nel diritto della Chiesa. Il principio - nullum crimen sine lege - nel diritto canonico, Rivista intenazionale di Filosofia del Diritto 36 (1959) $564 \mathrm{nn}$. 
zowną do zindywidualizowania kary $\mathrm{w}$ konkretnym wypadku, a co za tym idzie, do sprawiedliwego jej wymiaru, czyli do dostosowania kary do wielkości danego przestępstwa i winy jego sprawcy.

Ta ostatnia próba pogodzenia omawianych kanonów 2195 i 2222 $\S 1$ najbardziej trafia do przekonania i zdaje się dawać najlepsze rozwiązanie tego spornego zagadnienia.

\section{Wnioski de lege ferenda}

W ostatnich latach niektórzy autorzy, wypowiadający się przy różnych okazjach na temat zasady legalności w kanonicznym prawie karnym lub interpretacji omawianych wyżej kanonów, mając na uwadze bliską reformę Kodeksu, wysuwają pewne wnioski de lege ferenda. Nie są one jednak jednomyślne. Zdania tych autorów dadzą sie sprowadzić do trzech zasadniczych opinii:

a) Jedni akceptują i popierają obecne ujęcie tego zagadnienia w Kodeksie. Dla ścisłości można ich podzielić na dwie grupy.

1. Wielu nie wypowiada wprawdzie wyraźnie sformułowanych wniosków de lege ferenda, lecz stwierdza ogólnie, że rygorystyczne zastosowanie zasady legalności nie odpowiada duchowi i charakterowi kościelnego prawa karnego. Zbawienie bowiem ludzi, stanowiące naczelne zadanie Kościoła i stąd najwyższą normę w kościelnym porządku prawnym, jak dawniej tak i dziś wymaga w kanonicznym prawie karnym dużej elastyczności, jakiej nie znają ustawodawstwa państwowe. Przepis kan. $2222 \S 1$, choć spowodował tak rozległą i długotrwałą dyskusję, stanowi normę łagodząca zasadę legalności w kościelnym prawie karnym i nadającą jej tę wymaganą $w$ prawie kanonicznym elastyczność. Nie należy go więc usuwać z Kodeksu, gdyż swoboda przełożonych kościelnych w ocenianiu czynów ludzkich i karceniu swych podwładnych środkami karnymi, która w myśl zasady ,summa lex salus animarum" podyktowała prawodawcy kościelnemu ten przepis, jest bardziej właściwa i użyteczna prawu kanonicznemu, niż bezwzględna zasada legalności. Nawet gdyby ten przepis nie został w Kodeksie umieszczony, to kościelne prawo karne nie mogłoby się obejść bez istotnych elementów w nim zawartych. Aby zaś ten kanon nie budzil tyle zastrzeżeń i nie wywoływal dalszej bezużytecznej dyskusjii nad pogodzeniem go $z$ zasadą legalności, nauka prawa kanonicznego powinna dążyć do jasnego i wnikliwego opracowania jego treści, zwłaszcza sprecyzowania warunków, w których miałby on praktyczne zastosowanie, tzn, pojęcia zgorszenia i specjalnie ciężkiego wykroczenia przeciwko prawu kościelnemu ${ }^{44}$.

${ }^{44} \mathrm{~W}$ ten mniej więcej sposób wypowiadają się: Fedele P., Il prin- 
2. Inni natomiast, zatrzymując $\mathrm{w}$ pełni treść kanonu $2222 \S 1$ który traktują jako wyjątek od kan. 1195. lagodzący zawartą w nim zasadę legalności, proponują wprowadzenie do tych przepisów pewnych modyfikacji.

I tak np. A. Szentrimai wysuwa wniosek, by treścią kan. $1195 \S 1$ objąć również przepis pierwszej części kan. 2222 § 1 i przestępstwo kościelne określić jako ,...pogwałcenie ustawy, które jest zagrożone sankcją kanoniczną przynajmniej nie oznaczoną lub $z$ uwagi na szczególną swą ciężkość albo dane zgorszenie zasługuje w myśl kanonu $2222 \S 1$ na karę" 45.

H. Herrman zaś proponuje połączyć §§ $1-2$ kan. $1195 \mathrm{w}$ jeden przepis i nadać mu brzmienie: „Przez przestępstwo w prawie kościelnym rozumie się zewnętrzne i moralnie poczytalne pogwałcenie ustawy obłożonej sankcją kanoniczną, przynajmniej nieokreśloną, lub - jeżeli $z$ okoliczności inaczej nie wynika - rozkazu karnego" 46. W odniesieniu zaś do przepisu kan. 2222 sugeruje, by go ując w trzech oddzielnych paragrafach. W pierwszym radzi wyraźnie uwypuklić zasadę wyrażoną już w kan. 1195, że można karać tylko tego, kto $\mathrm{w}$ myśl kan. 1195 dopuścil się zagrożonego sankcją pogwałcenia ustawy albo rozkazu. W ten sposób chce podkreślić, że $z$ reguly przełożony kościelny nie może karać za przekroczenie ustawy lub rozkazu, jeżeli one nie zawierają $w$ sobie sankcji karnej. Sądzi bowiem iż to podkreślenie zabezpieczy podwładnych przed ewentualną dowolnością i nadużyciami ze strony przełożonych w karceniu wykroczeń przeciwko prawu kościelnemu. W \& 2 umieszcza pierwsze zdanie dotychczasowego kan. $2222 \S 1$ (licet, ferat), chcąc $w$ ten sposób położyć akcent na charakter tego przepisu jako wyjątku od zasady wyrażonej w kan. 1195 i powtórzonej w proponowanym kan. $2222 \S 1$.

cipio - nullum crimen sine lege penali - e il diritto penale canonico, Rivista Italiana di Diritto Penale, 1937, n. 5; La certezza del diritto e l'ordinamento canonico, Archivio di Diritto Ecclesiastico, $1943,360 \mathrm{nn}$.; Lo spirito del diritto canonico, $222 \mathrm{n}$. i $813 \mathrm{i} \mathrm{nn}$.; B ellini P. Osservazioni sulla completezza dell'ordinamento giuridico canonico, iì Diritto Ecclesiastico, 1957, I, 207, nota 80 i 233, nota 96; V it ale A., Contributo ad una eoria delle sanzioni nell'ordinameno canonico, Ephem. iur. can. 18 (1962) n. $2-3$, s. 282 nn.; Strig 1 R. A., Das Funktionsverhaltnis zwischen kirchlicher Strafgewalt und Offentlichkeit, München 1965, 208-212; P e per on i S., dz. c., 73 n.

${ }_{45} \mathrm{Szentirmai}$ A., Quaestiones de iure poenali canonico hodiernis necessitatibus accommodato, Nonitor Ecclesiasticus, 87 (1962) 608. „Nomine... eterna et moraliter imputabilis legis violatio cui addita sit sanctio canonica saltem indeterminata vel quae ob specialem granitatem scandalumve forte datum, ad normam can. $2222 \& 1$, punienda videatur".

${ }^{46} \mathrm{H}$ errmann H., art. c., 19 proponuje: c. 2195 ,Nomine delicti, iure ecclesiastico, intelligitur externa et moraliter imputabilis legis vel, nisi ex adiunctis aliud appareat, praecepti violatio cui addita si sanctio canonica saltem indeterminata". 
Do tego paragrafu autor dołącza klauzulę zastrzegającą karanemu sprawcy prawo do odwolania się do wyższej instancji. Tego rodzaju klauzula przy normie będącej wyjątkiem od ogólnej reguły zawartej w proponowanych kan. 1195 i $\S 1$ kan. 2222 ma stanowić wyraźne ostrzeżenie dla przelożonych, by nie działali przynajmniej zbyt pochopnic, a oskarżonemu ma zapewnić wystarczający środek prawny zabezpieczający go przed dowolnością ze strony przełożonych.

Ponadto proponuje skreślenie $\mathrm{w}$ tym przepisie przymiotnika „datum" przy wyrazie ,scandalum", zaznaczając że przełożony powinien być na mocy tego kanonu uprawniony do interwencji nie tylko w wypadku zgorszenia juz faktycznie spowodowanego, lecz również w razie grożącego niebezpieczeństwa wywołania zgorszenia. Prócz tego wyraz, gravitas" (transgressionis) radzi zastąić słowem "qualitas", które ma szerszy zakres i obejmuje wyraźnie tak stronę materialną czynu - wielkość bezprawia - jak i formalną - stopień zawinienia 47. Takie ujęcie wskazuje wyraźnie, że przelożony może wymierzyć słuszna karę również i w wypadku, gdy czyn nie stanowi wprawdzie szczególnie wielkiego bezprawia, ale ze względu na szczególny stopień zawinienia zasługuje na ukaranie.

Jak z tego widać autor rozszerza nieco w swoich propozycjach zakres omawianego kanonu.

b) Niektórzy autorzy posuwają się jeszcze dalej i ze względu na specjalny charakter kościelnego prawa karnego, które — mając pomagać Kościołowi w zbawianiu ludzi — wymaga większej elastyczności w stosowaniu środlków karnych, proponują rozszerzenie możliwości stosowania przepisu kan. $2222 \S 1$. Wysuwają mianowicie myśl, że dla uproszczenia kościelnego prawa karnego można by tak zredagować ten kanon, by przyznać przełożonemu kościelnemu władzę karania w miarę potrzeby wykroczeń przeciwko przepisom prawa kanonicznego, nie zagrożonym sankcją karną, również $w$ pewnych wypadkach obecnie nie przewidzianych w tym. kanonie, tzn. poza wypadkiem gorszącego i specjalnie cięzkiøgo wykroczenia. Niebezpieczeństwo ewentualnych nadużyć takiego uprawnienia ze strony przełożonych wydaje się $w$ oparciu o dotychczasową praktykę minimakne ${ }^{48}$.

47 Tenże: c. $2222 \S 1$, Reus puniri nequit, nisi legem vel praeceptum, quorum transgressioni sanctio addita sit, ad normam can. 2195 violaverit.

$\S 2$. Si autem scandalum forte aut specialis transgressionis qualitas id ferant, licet sanctio desit, legitimus Superior potest violationem legis vel praecepti aliqua iusta poena punire, etiam sine praevia poenae comminatione, salvo autem iure recursus.

\& 3. - Obecny \& 2.

${ }_{48}$ Tak np. Sche uermann A., Erwagungen zur kirchlichen Strafrechisreform, Archiv für katholisches Kirchenrecht 131 (1962) 407-408. 
c) Inni znów autorzy są przeciwnego zdania. Wypowiadają się za skreśleniem z Kodeksu tego przepisu i zmodyfikowaniem kan. 2195. Podaja różne ku temu racje.

I tak O. Cassola ${ }^{49}$ zwraca uwage na fakt, że Kościól posiada już od długiego czasu dostatecznie pełny wykaz określonych przestępstw zagrożonych karami, który całkowicie wystarcza do ochrony porządku publicznego i karności w Kościele. Przy czym powszechne prawo karne Kościola jest wspierane ustawodawstwem partykularnym. Ponadto $w$ wielu poszczególnych wypadkach istnieje możliwość wymierzania kar w trybie administracyjnym przy pomocy nakazu lub zakazu karnego albo upomnienia polączonego $z$ zagrożeniem kary. Srodki te wystarczająco pozwalają zabezpieczyć sankcją karną każdy przepis prawa kościelnego w wypadku, gdyby groziło niebezpieczeństwo społecznie szkodliwego pogwalcenia go. W rzadkich zaś wypadkach gorszącego lub szczególnie ciężkiego naruszenia jákiegoś przepisu prawnego, nie obłożonego sankcją karną, istnieje możliwość zastosowania nagany (kan. 2308), do której w razie potrzeby można dołączyć odpowiednią pokutę (kan. $2312,2313 \S 2$ ). Następnie, gdyby nagana nie odniosła skutku, albo gdyby nie było można go się spodziewać, przełożony może się posłużyć rozkazem karnym (kan. 2310). Ponadto wzgląd na podkreślaną coraz bardziej godność osoby ludzkiej zdaje się domagać, by również w prawie kanonicznym, jako porządku prawnym szczególnie doceniającym godność osoby ludzkiej, znajdowala pełne zastosowanie zasada legalności, tak iżby każdy z góry wiedział, co. go czeka za określone naruszenie prawa kościelnego. Stąd należało by w nowym kodeksie prawa kanonicznego odpowiednio zmienić olkreślenie przestępstwa, wyrażonego obecnie w kan. 2195, oraz przepis kan. $2222 \xi 1$, usuwając z niego pierwsze zdanie, stanowiące wyjątek $\mathrm{w}$ stosunku do zasady legalności zawartej $\mathrm{w}$ definiciji przestępstwa. Autor proponował przed kilku laty następujące określenie przestępstwa: „przez przestępstwo $\mathrm{w}$ prawie kościelnym rozumie się zewnętrzne i moralnie poczytalne pogwałcenie ustawy lub rozkazu, które jest zagrożone kanoniczną sankcją karną" 50. Zaznacza przy tym, że można pozostawić interpretacji przyrównanie do rozkazu upomnienia połączonego $z$ zagrożeniem karnym. Tego samego zdania jest również J. Baldanza ${ }^{51}$.

Ostatnio O. Cassola posunął się o pewien krok dalej. Publikując swój projekt pierwszej części V księgi Kodeksu prawa kanonicznego, podaje określenie przestępstwa kościelnego bardzo podobne

${ }^{49}$ Cass ola O., Natura e divisione del delitto, Apollinaris 34 (1961) n. $3-4,336 \mathrm{n}$.

so Tamże.

s1 $\mathrm{B}$ a I d a $\mathrm{n}$ a I., De recognoscendo iure canonico poenali quaestiones quaedam, Ephem. iur, can. 19 (1963) n. 1-2, 100. 
do definicji przyjętej w ustawodawstwach państwowych - „przestępstwem kościelnym jest zewnętrzne i moralnie poczytalne pogwałcenie kościelnej ustawy karnej" 52.

Proponowana definicja przestępstwa wylączylaby możliwość stosowania przez przełożonych kościelnych $\mathrm{w}$ wymiarze kar rozkazów karnych i upomnień zagrażających sankcją karną. W uzasadnieniu swego stanowsika ąutor stwierdza, że dotychczasowe przepisy kan. $2195 \S 2$ i $2222 \S 1$ są sprzeczne z powszechnie dziś przyjętą zasadą legalności $\mathrm{w}$ prawie karnym i prowadzą do zbytniego rozszerzenia zakresu karalności, czyli do mnożenia przestępstw i kar zupełnie niepotrzebnych dla ochrony kościelnego porządku publicznego: Ochronę tę bowiem dostatecznie zabezpieczają ustawy karne - powszechne czy partykularne jak również pozostałe środki zabezpieczające i pokuty, talk że nie ma potrzeby uciekać się do stosowania rozkazów karnych lub korzystania $z$ uprawnienia przyznanego przełożonym w kan. $2222 \S 1$. Przy takim ujęciu również i w prawie kanonicznym znalazłaby pełne zastosowanie zasada legalności. Wskutek czego kara mogłaby w wyższym stopniu spełniać bardzo ważną w życiu społecznym funkcję prewencji ogólnej, czyli wywierania na podwładnych przymusu psychologicznego w kierunku przestrzegania prawa kościelnego i unikania czynów naruszających je, gdyż wszyscy uprzednio wiedzieliby, co im grozi za określone bezprawne zachowanie się ${ }^{53}$.

Podobnie za pełnym uwzględnieniem w nowej kodyfikacji kościelnego prawa karnego zasady: „Nullum crimen nullaque poena sine lege poenali praevia" wypowiedział się na Międzynarodowym Zjeździe Kanonistów w Rzymie (20-25.V.1968 r.) I. Herrenz, członek Papieskiej Komisji dla Reformy Kodeksu. W swoim odczycie na temat zasady legalności $w$ prawie kanonicznym podkreślił, że przyszłe ustawodawstwo kościelne - jeżeli nie ograniczy swego systemu sankcji do pewnego katalogu pokut pasterskich, a przeciwnie będzie chciało zawierać prawdziwe prawo karne - będzie musiało między innymi w pełni zastosować zasadę legalności 54 .

Co o tych sugestiach sądzić?

Wziąwszy pod uwagę wysunięte $\mathrm{w}$ tych opiniach argumenty, należaloby się chyba opowiedzieć za trzecim wnioskiem, tzn. za usunięciem z Kodeksu przepisu kan. $2222 \S 1$ i jasnym uwypukleniem w określeniu przestępstwa kościelnego zasady legalności, jak to proponuje O. Cassola.

52 Cassola O., Specimen partis primae libri $V$ C. I. C. reformatae proponitur, w: Miscellanea in kan. D. Staffa et P. Felici, Apollinaris 40 (1967) 457: "Violatio externa et moraliter imputabilis legis poenalis ecclesiasticae".

53 Tamże.

54 Por. Pier on ek T., Miedzynarodowy Zjazd Kanonistów (Rzym, 20-25. V. 1968 r.), Prawo Kanoniczne 12 (1969) 3-4, s. 377. 
Przyznać niewątpliwie trzeba, że kościelne prawo karne ma charakter specjalny, sobie tylko właściwy, gdyż wchodzi w skład systemu prawnego społeczności specyficznej i jako taki, nie tylko stoi na straży porządku społecznego i dobra publicznego Kościoła, ale ma również służyć jako odpowiednie narzędzie w rękach Kościoła do zbawienia indywidualnych ludzi. Musi więc się odznaczać właściwą sobie elastycznością.

Zważywszy jednak na wymienione wyżej możliwości przełożonych kościelnych $w$ dziedzinie karcenia podwładnych, naruszających przepisy prawa kanonicznego, nie wydaje się weale, by zniesienie tego przepisu, powodującego tyle wątpliwości i trudności interpretacyjnych, oraz wyraźne podkreślenie zasady legalności przyniosło szkodę kościelnemu prawu karnemu i nastręczało trudności w realizowaniu szczytnego zadania Kościoła - zbawiania ludzi, jak to starają się wykazać autorzy opowiadający się za utrzymaniem lub rozszerzeniem tego przepisu.

Trzeba też stwierdzić, że wzgląd na godność osoby ludzkiej coraz częściej i mocniej podkreślaną w nauce Kościoła - jest bardzo ważnym argumentem za zmodyfikowaniem omawianych przepisów prawa kanonicznego i pełnym zastosowaniem zasady legalności w kościelnym prawie karnym. Tym bardziej, że w czasie dyskusji nad nowym kodeksem prawa kanonicznego na Synodzie Biskupów mocno podkreślano konieczność uwzględnienia w nowym prawodawstwie kościelnym zagadnienia uprawnień osoby ludzkiej. Postulowano tam też, by nowy Kodeks, idąc za głosem ostatnich Papieży i uchwał soborowych, wziął pod uwagę głębokie przemiany w sposobie myślenia i odczuwania dzisiejszego człowieka 55. Zasada legalności w prawie karnym jest dziś przyjęta w większości ustawodawstw państwowych. W oparciu o nią ukształtowała się już mentalność i poczucie prawne całych spoleczeństw $\mathrm{w}$ odniesieniu do wymiaru sprawiedliwości karnej. Stąd wydaje się rzeczą wskazaną, by nowe prawodawstwo kościelne ją jasno uwypukliło i w pełni zastosowało, zeby nie wprowadzać bez potrzeby dysonansu między prawem kościelnym a ukształtowana na zasadzie legalności mentalnością i poczuciem prawnym wiernych, jak równiez by nie darwać powodu do różnego rodzaju zastrzeżeń pod adresem prawa kanonicznego.

Przepis bowiem kan. $2222 \S 1$ sprawia, że - praktycznie biorąc - system kościelnego prawa karnego, aczkolwiek jest normowany w V księdze Kodeksu, rozciąga się na cały Kodeks, gdyż każde ciężkie lub połączone ze zgorszeniem przekroczenie jakiegokolwiek przepisu kodeksowego może być karane. Takie zaś uję-

55 Por. Przybyia A., Prawo kanoniczne $w$ świetle obrad Synodu Biskupów, Ateneum Kapł̇ańskie 60 (1968) z. 3-4, s. 170. 
cie bardzo razi współczesnego człowieka. Przypomina bowiem stare kodyfikacje, w których przepisy karne były rozrzucone po całym tekście ustawy i znacznie przeważały nad innymi działami prawa.

Tak więc również wedłung mego skromnego przekonania kan. $2222 \S 1$, aczkolwiek — jak wyżej stwierdzono — da się jakoś w drodze skomplikowanej interpretacji pogodzić z kan. 2195 i nie zdaje się całkowicie wykluczać zasady legalności, ze względu jedno.k na przedstawione wyżej racje powinien być zupełnie pominięty w przyszlym kodeskie prawa kanonicznego. Kanon zaś określający przestępstwo kościelne powinien jasno uwypulklać bezwzględną zasadę legalności.

\section{SUMMARIUM}

\section{Principium legalitatis in iure canonico}

Sic dictum principium legalitatis, quod in celeberrimo effato: „, nullum crimen nullaque poena sine lege poenali praevia" exprimi solet atque in hodierna iuris poenalis doctrina universaliter agnoscitur ef plerunque in hodiernis codicibus statalibus plene applicatur, constituit in doctrina iuris canonici quaestionem quam maxime complicatam ef controversam. Quamquam iam pluries apud canonistas consideratum et acerrime discussum fuit, nihilominus adhuc haud paucis ambiguitatibus et difficultatibus scatet, praesertim si agitur de interpretatione et conciliatione canonum $2195 \& 1$ et $2222 \& 1$, quorum primus regulam illud principium affirmantem statuit, alter vero exceptionem ab illo exprimere videntur. Quapropter nonnulli auctores, habita ratione novae iuris canonici codificationis, hanc quaestionem data occasione in variis ephemeridibus iuris canonici tangunt atque sua vota de lege ferenda circa hanc rem exponunt. Quae opiniones haud consortes sunt. Utile igitur videtur illas opiniones generatim paucis tantum verbis expressas in unum colligere easque profundiori examini subiicere atque rem pro posse magis delucidare.

Praecedens articulus quinque capitulis constat.

I. In primo capitulo, subnotato discrimine inter praefatum principium et conceptus affines, utpote retroactivitas legis, analogia vel interpretatio lata in re poenali vitanda, strictus sensus atque extensio huius principii exponitur.

II. In altero ostenditur origo atque indoles iuridica praefati principii. Animadvertitur scilicet, quod praevia delicti determinatio et poenae ab eius auctore incurrencae comminatio minime ex rerum natura requiritur, sed ab ipsa quctoritate sociali, uti exigentiis rectae politicae criminalis quam maxime consentanea, in ius poenale introducta est.

III. In tertio autem capitulo brevis evolutio historica principii legalitatis in iure poenali tam statali quam ecclesiastico delineatur. Ad ius canonicum quod attinet, animadvertitur nullum in fontibus iuridicis ante Codicem vigentibus inveniri textum, qui hoc principium formaliter aut saltem aequivalenter enuntiet. In antiquo iure canonico certe non existebat taxativus catalogus actuum punibilium a priori determinatorum et propriis poenis munitorum, ita ut quaelibet gravis legis violatio a legitimis Superioribus ecclesiasticis libere secundum cor un- 
dem arbitrium puniri posset. Paulatim tamen, cum systema iuris criminalis Ecclesiae magis magisque in dies evolvebatur, delicta propriis poenis plectenda accuratius legibus determinabantur et usus abtinuit, ut revera non punirentur tamquam delicta, nisi violationes normarum ecclesiasticarum praevia poena munitarum. Quo ex usu praevaluit in doctrina canonistica communis opinio quod legis ecclesiasticae violotio generatim puniri nequit sine praevia poenae comminatione.

IV. Deinde examinantur auctorum opiniones interpretationem et concordantiam canonum $2195 \S 1$ et $2222 \S 1$ respicientes, quae ad quatuor praecipuas classes redici possunt:

1. Iuxta quosdam auctores principium legalitatis in iure poenali ecclesiastico plene recognostitur atque duo citati canones conciliari possunt hoc in sensu, quod can. $2195 \& 1$, describendo delictum proprie dictum, plene affirmat principium legalitatis - universim et sine exceptione pro omnibus delictis validum; dum can. $2222 \S 1$ agit de legis violationibus quae delictis tantum aequiparantur, sed delicta proprie dicta non sunt.

2. Alii vero opinantur praescriptum can. $2222 \S 1$ constituere manifestam exceptionem a principio legalitattis, quod in can. $2195 \S 1$ continetur, ita ut in iure poenali canonico revera in casibus praescripto can. $2222 \& 1$ determinatis puniatur legis violatio sine praevia poene comminatione.

3. Alii affirmant semper in iure canonico requiri legem poenalem, ut verum delictum habeatur. Ad illos duos canones conciliandos dispositionem exceptionalem can. $2222 \& 1$ considerant tamquam specialem applicationem principii retroactivitatis legis, hoc nempe sensu, quod actus Superioris poenam vi facultatis ipsi in citato canone concessae deternimantis et reo infligentis habet vim retroactivam et violatam legem antea non poenalem eo ipso in poenalem transformat.

4. Iuxta alios demum auctores praescriptum can. $2222 \S 1$ constituit normam generalem, vi cuius praevie statuitur sanctio poenalis indeterminata pro omnibus casibus scandalosae aut specialiter gravis transgressionis cuiuslibet legis ecclesiasticae. Exinde norma huius canonis minime contraria est principio generali in can. $2195 \S$ enuntiato. Etenim quoque in casibus can. $2222 \S 1$ praevisis habetur sanctio poenalis praevia in lege statuta, ita ut principium legalitatis in iure poenali ecclesiastico nulam patiatur exceptionem.

Quae interpretatio, quamvis valde complicata appareat, magis placet quam praecedentes eisque praeferenda videtur, nam citatos duos canones optime conciliat.

V. In ultimo capitulo recensentur postulata de lege ferenda a quibusdam auctoribus hac in re proposita, quae ad tres praecipuas opiniones reducuntur.

1. Non pauci affirmant dispositionem can. $2222 \S 1$ omnino in novo Codice retinendam esse ald elasticitatem juri poenali canonico propriam ac necessariam rite conservandam. Non - nulli quasdam parvas tantum modificationes allegatorum canonum proponunt, ut quaestio magis elucidari ac difficultates inter - pretativas evitari possint.

2. Alii immo quandam extensionem potestatis Superioribus ecclesiasticis vi can. $2222 \S 1$ concreditae suggerunt.

3. Alii demum ad inutilles circa hanc rem disputationes evitandas atque eventuales abusus in iustitia poenali administranda praecavendos nec non ad dignitatem personae humanae magis in iure canonico subnotandam et ius poenale ecclesiasticum mentis habitui hodiernis homi- 
nis magis accommodandum aliasque ob rationes dispositionem can. 2222 $\$ 1$ penitus in novo Codice praetermitten dam esse opinantur.

Ferpensis rationibus, in quibus allatae opiniones fundantur, ultimo voto subscribendum esse videtur, ita scilicet ut can, 2222 omnino abrogetur et in apta delicti ecclesiastici definitione principium legalitatis rite affirmetur. 